\title{
Influence of Alloying Element Addition on Cu-Al-Ni High- Temperature Shape Memory Alloy without Second Phase Formation
}

\author{
Xin Zhang ${ }^{1} \cdot$ Qing-Suo Liu ${ }^{1}$
}

Received: 21 April 2016/Revised: 24 May 2016/Published online: 20 July 2016

(C) The Chinese Society for Metals and Springer-Verlag Berlin Heidelberg 2016

\begin{abstract}
In this study, the effects of rare earth Gd and Fe elements on the microstructure, the mechanical properties and the shape memory effect of $\mathrm{Cu}-11.9 \mathrm{Al}-3.8 \mathrm{Ni}$ high-temperature shape memory alloy were investigated by optical microscopy, scanning electron microscopy, X-ray diffraction and compression test. The microstructure observation results showed that both $\mathrm{Cu}-11.9 \mathrm{Al}-3.8 \mathrm{Ni}-0.2 \mathrm{Gd}$ and $\mathrm{Cu}-11.9 \mathrm{Al}-3.8 \mathrm{Ni}-2.0 \mathrm{Fe}-0.2 \mathrm{Gd}$ alloys displayed the fine grain and singlephase $\beta_{1}^{\prime}$ martensite, and their grain size was about several hundred microns, one order of the magnitude smaller than that of $\mathrm{Cu}-11.9 \mathrm{Al}-3.8 \mathrm{Ni}$ alloy. The compression test results proved that the mechanical properties of $\mathrm{Cu}-11.9 \mathrm{Al}-3.8 \mathrm{Ni}$ alloy were dramatically improved by alloying element additions due to grain refinement and solid solution strengthening, and the compressive fracture strains of $\mathrm{Cu}-11.9 \mathrm{Al}-3.8 \mathrm{Ni}-0.2 \mathrm{Gd}$ and $\mathrm{Cu}-11.9 \mathrm{Al}-3.8 \mathrm{Ni}-2.0 \mathrm{Fe}-0.2 \mathrm{Gd}$ were $12.0 \%$ and $17.8 \%$, respectively. When the pre-strain was $10 \%$, the reversible strains of $5.4 \%$ and $5.9 \%$ were obtained for $\mathrm{Cu}-11.9 \mathrm{Al}-3.8 \mathrm{Ni}-$ $0.2 \mathrm{Gd}$ and $\mathrm{Cu}-11.9 \mathrm{Al}-3.8 \mathrm{Ni}-2.0 \mathrm{Fe}-0.2 \mathrm{Gd}$ alloys after being heated to $500{ }^{\circ} \mathrm{C}$ for $1 \mathrm{~min}$, and the obvious two-way shape memory effect was also observed.
\end{abstract}

KEY WORDS: High-temperature shape memory alloys; Shape memory effect; Microstructure; Cu-Al-Ni alloy

\section{Introduction}

Nowadays, high-temperature shape memory alloys (HTSMAs), such as Ti-Ni-Pd, Ti-Ta, Ta-Ru and Ni-Mn$\mathrm{Ga}$ [1-12], have attracted worldwide attentions. $\mathrm{Cu}-\mathrm{Al}-\mathrm{Ni}$ HTSMAs are particularly interesting because of their low producing cost in comparison with above well-studied HTSMAs. However, polycrystalline $\mathrm{Cu}-\mathrm{Al}-\mathrm{Ni}$ alloys suffer from high brittleness, which is associated with large elastic anisotropy, intergranular cracking and large grain

Available online at http://link.springer.com/journal/40195

Xin Zhang

zhangxin3510110@126.com

1 School of Materials Science and Engineering, Tianjin University of Technology, Tianjin 300384, China size [13-17]. Some methods were adopted to improve the mechanical properties of polycrystalline $\mathrm{Cu}-\mathrm{Al}-\mathrm{Ni}$, including grain refinement [18] and fourth element addition [13, 19-21]. However, most of the grain refinement methods such as powder metallurgy and spark plasma sintering are complicated and expensive. Meanwhile, the second phase formation induced by fourth element addition is harmful to the shape memory effect (SME).

It is well known that rare earth doping significantly enhances the mechanical properties of the shape memory alloys [22-24]. For example, proper rare earth Gd addition can refine the grain of Ni-Mn-Ga HTSMA without second phase formation and enhances the mechanical properties [23], and this mono-phase $\mathrm{Ni}-\mathrm{Mn}-\mathrm{Ga}$ alloy with fine grain displays outstanding SME. Therefore, $\mathrm{Cu}$ element of $\mathrm{Cu}-$ Al-Ni HTSMA is substituted by a small amount of Gd to refine grain in the present work. In addition, Fe element is 
used to further toughen the $\mathrm{Cu}-\mathrm{Al}-\mathrm{Ni}-\mathrm{Gd}$ alloy. The effects of alloying elements on the microstructure, mechanical properties and SME of $\mathrm{Cu}-\mathrm{Al}-\mathrm{Ni}$ HTSMA are investigated.

\section{Experimental}

The nominal compositions of the studied alloys were $\mathrm{Cu}-$ $11.9 \mathrm{Al}-3.8 \mathrm{Ni}, \mathrm{Cu}-11.9 \mathrm{Al}-3.8 \mathrm{Ni}-0.2 \mathrm{Gd}$ and $\mathrm{Cu}-11.9 \mathrm{Al}-$ $3.8 \mathrm{Ni}-2.0 \mathrm{Fe}-0.2 \mathrm{Gd}$ (wt\%), which were marked as $\mathrm{Cu}_{1}$, $\mathrm{Cu}_{2}$ and $\mathrm{Cu}_{3}$, respectively. High purity copper, aluminum, nickel, gadolinium and iron $(\geq 99.97 \mathrm{wt} \%)$ were melted in a non-consumed vacuum arc furnace. The ingots were remelted six times to ensure homogeneity. The samples were annealed in a vacuum quartz tubes at $850{ }^{\circ} \mathrm{C}$ for $24 \mathrm{~h}$ and subsequently quenched into ice water.

The microstructures were studied using optical microscopy, X-ray diffraction (XRD, Rigaku D/max-rB with $\mathrm{Cu}$ $K_{\alpha}$ radiation) and scanning electron microscopy (SEM, Quanta 200FEG with EDS equipment). The transformation temperatures were determined by PerkinElmer Diamond differential scanning calorimetry with heating and cooling rate of $20^{\circ} \mathrm{C} / \mathrm{min}$. The martensitic transformation starting temperatures $\left(M_{\mathrm{s}}\right)$ of $\mathrm{Cu}_{1}, \mathrm{Cu}_{2}$ and $\mathrm{Cu}_{3}$ are 224, 223 and $227^{\circ} \mathrm{C}$, respectively. The compression and SME tests were performed at room temperature on Instron 5569 testing system at a crosshead displacement speed of $0.2 \mathrm{~mm} / \mathrm{min}$, and the size of the samples was $\Phi 3 \mathrm{~mm} \times 5 \mathrm{~mm}$. The heights of the samples were measured before loading $\left(L_{0}\right)$, after loading $\left(L_{1}\right)$, after unloading $\left(L_{2}\right)$, after heating to $500{ }^{\circ} \mathrm{C}$ for $1 \mathrm{~min}\left(L_{3}\right)$ and after cooling to room temperature $\left(L_{4}\right)$ by a micrometer with an accuracy of $0.01 \mathrm{~mm}$. The pre-strain during compression was defined as $\varepsilon_{\text {pre }}=\left(L_{0-} L_{1}\right) / L_{0} \times 100 \%$. The SME, recovery ratio and TWSME were obtained as $\left(L_{3}-L_{2}\right) / L_{0} \times 100,\left(L_{3}-L_{1}\right) /$ $\left(L_{0}-L_{1}\right) \times 100$ and $\left(L_{3}-L_{4}\right) / L_{0} \times 100 \%$, respectively.

\section{Results and discussion}

Figure 1 shows the optical micrograph and XRD pattern of solution-treated $\mathrm{Cu}_{1}$ alloy at room temperature. It can be seen that the grain size reaches millimeter level, and two kinds of martensites with different morphologies are observed. According to the reported martensitic morphology of $\mathrm{Cu}-\mathrm{Al}-\mathrm{Ni}$ alloy, the martensite with self-accommodating zigzag groups of variants can be concluded as $\beta_{1}^{\prime}$ $(18 \mathrm{R})$, and the coarse martensitic variants is $\gamma_{1}^{\prime}(2 \mathrm{H})$ $[25,26]$. The various planes corresponding to the different martensites are obtained by XRD pattern of $\mathrm{Cu}_{1}$ alloy. The peak of (122) is $\gamma_{1}^{\prime}$ phase, while (122), (0018), (128), (208)
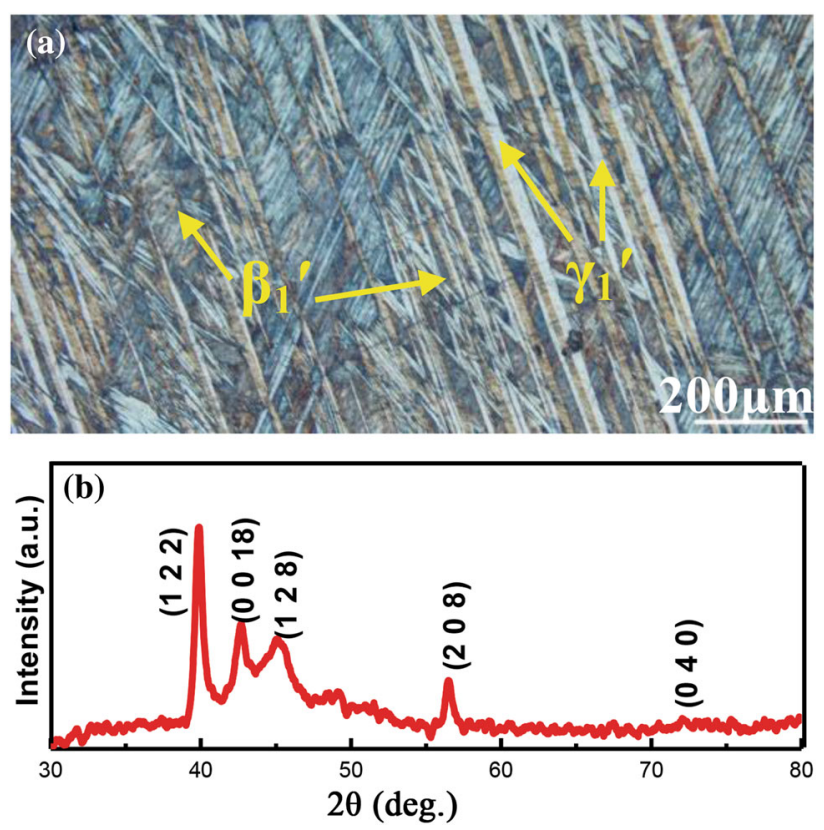

Fig. 1 Optical micrographs and $\mathrm{X}$-ray diffraction pattern of $\mathrm{Cu}_{1}$ alloy

and (040) belong to $\beta_{1}^{\prime}$ phase. The grain size, phase composition and martensitic morphology are similar to those of reported $\mathrm{Cu}-11.92 \mathrm{Al}-3.78 \mathrm{Ni}$ alloy [27].

Figure 2 shows the optical micrographs, backscattered electron images and XRD patterns of solution-treated $\mathrm{Cu}_{2}$ and $\mathrm{Cu}_{3}$ alloy at room temperature. The grain size of $\mathrm{Cu}_{2}$ alloy is about $200 \mu \mathrm{m}$ as shown in Fig. 2a, one order of the magnitude smaller than that of $\mathrm{Cu}_{1}$ alloy. When the $\mathrm{Fe}$ element is added, the grain size of $\mathrm{Cu}_{3}$ alloy remains unchanged as shown in Fig. 2b. In summary, proper $\mathrm{Gd}$ doping makes the grain size dramatically decrease, while Fe element doping has no effect on the grain size.

It can be seen from the backscattered electron images (Fig. 2c, d) that both $\mathrm{Cu}_{2}$ and $\mathrm{Cu}_{3}$ alloy display single phase of $\beta_{1}^{\prime}$ martensite with typical zigzag morphology, and no second phase is observed even if the Fe content is $2 \mathrm{wt} \%$. These results are consistent with the XRD results as shown in Fig. 2e, f. The compositions are measured by EDS and listed in Table 1. The results indicate that Gd and $\mathrm{Fe}$ are completely dissolved in the matrix.

In order to investigate the effect of alloying elements addition on the mechanical properties, compression tests are carried out at room temperature. Figure 3 represents the compressive stress-strain curves of $\mathrm{Cu}_{1}, \mathrm{Cu}_{2}$ and $\mathrm{Cu}_{3}$. The compressive fracture strength is significantly enhanced from 680 to $910 \mathrm{MPa}$ by $\mathrm{Gd}$ and $\mathrm{Fe}$ additions due to the refinement strengthening and solid solution strengthening. Furthermore, it should be noted that Gd and Fe additions improve compressive ductility also. The compressive fracture strains are only $7.1 \%$ for $\mathrm{Cu}_{1}$ alloy and $12.0 \%$ for 

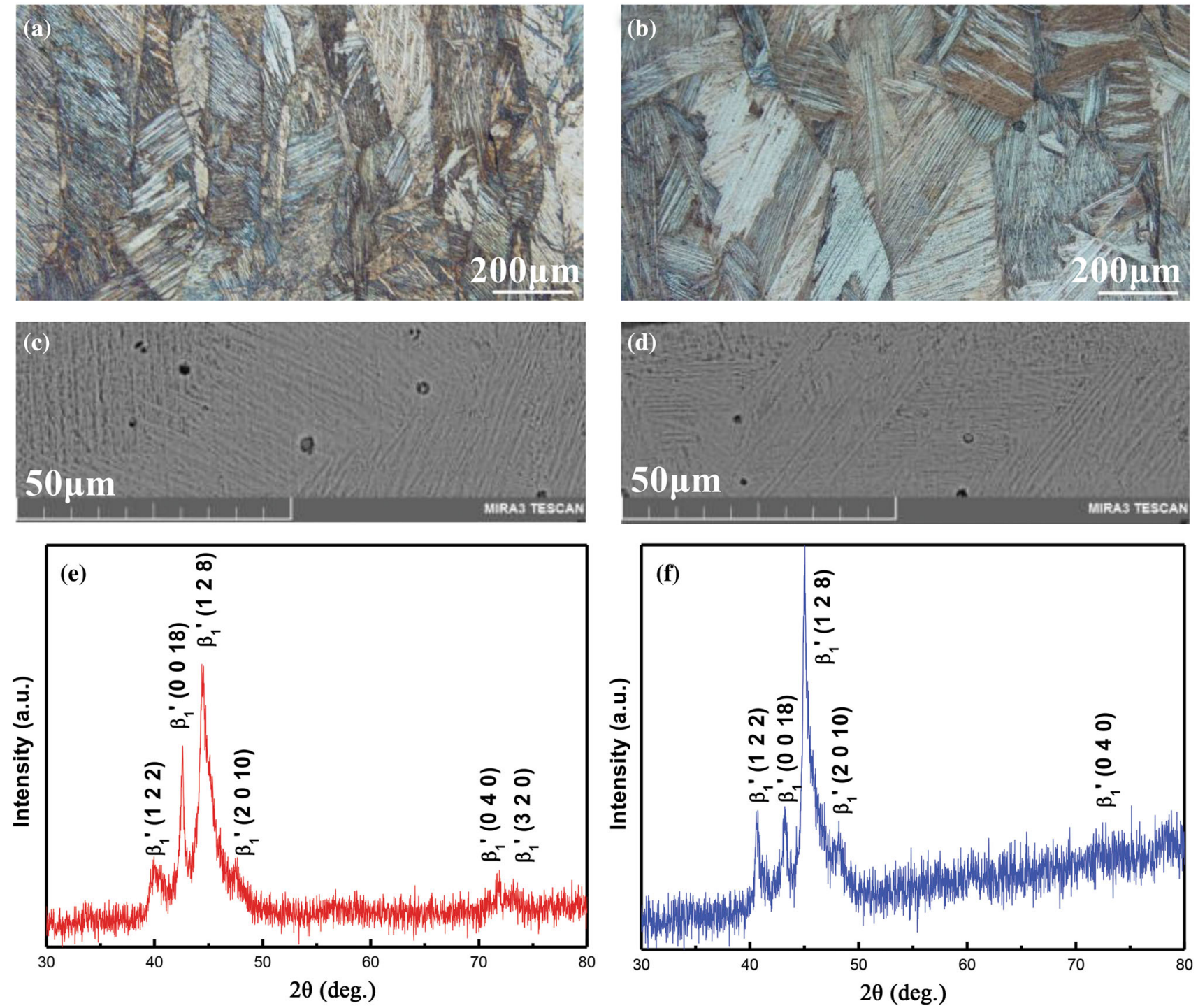

Fig. 2 Optical micrographs, backscattered electron images and X-ray diffraction pattern of $\mathrm{Cu}_{2} \mathbf{a}, \mathbf{c}$ and $\mathbf{e}$ and $\mathrm{Cu}_{3} \mathbf{b}, \mathbf{d}, \mathbf{f}$

Table 1 Results of the compositions examinations (wt\%)

\begin{tabular}{llllll}
\hline Sample & $\mathrm{Cu}$ & $\mathrm{Al}$ & $\mathrm{Ni}$ & $\mathrm{Gd}$ & $\mathrm{Fe}$ \\
\hline $\mathrm{Cu}_{1}$ & 83.82 & 12.21 & 3.97 & - & - \\
$\mathrm{Cu}_{2}$ & 83.67 & 12.18 & 3.92 & 0.23 & - \\
$\mathrm{Cu}_{3}$ & 81.5 & 12.27 & 4.01 & 0.19 & 2.03 \\
\hline
\end{tabular}

$\mathrm{Cu}_{2}$ alloy due to the grain refinement. Fe addition further increases the compressive fracture strain to $17.8 \%$. Published results showed that the proper alloying element can improve the ductility without $\gamma$ phase formation, and this phenomenon is attributed to the alloying elements addition enhancing the grain boundary [28]. As a result, it can be inferred that the compressive fracture strain of $\mathrm{Cu}_{3}$ alloy is

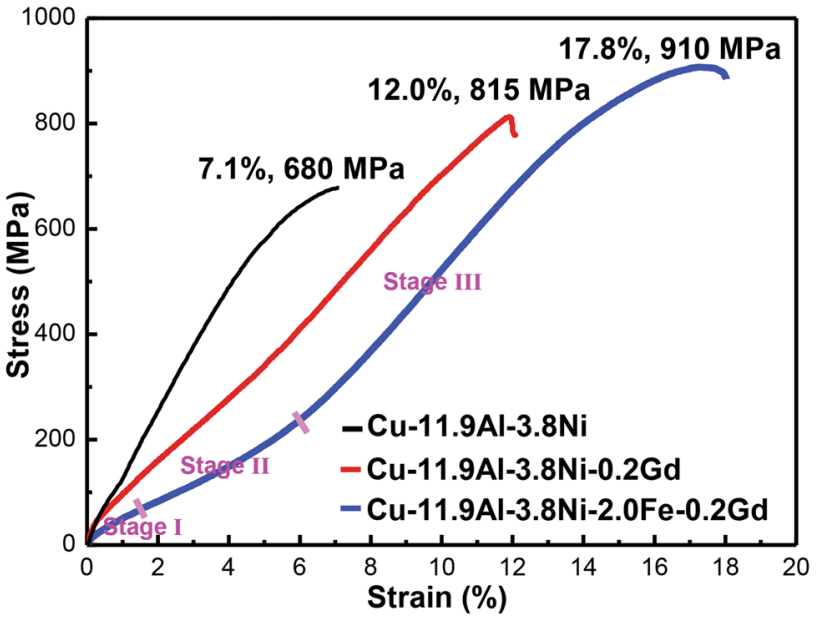

Fig. 3 Stress-strain curves of $\mathrm{Cu}_{1}, \mathrm{Cu}_{2}, \mathrm{Cu}_{3}$ 

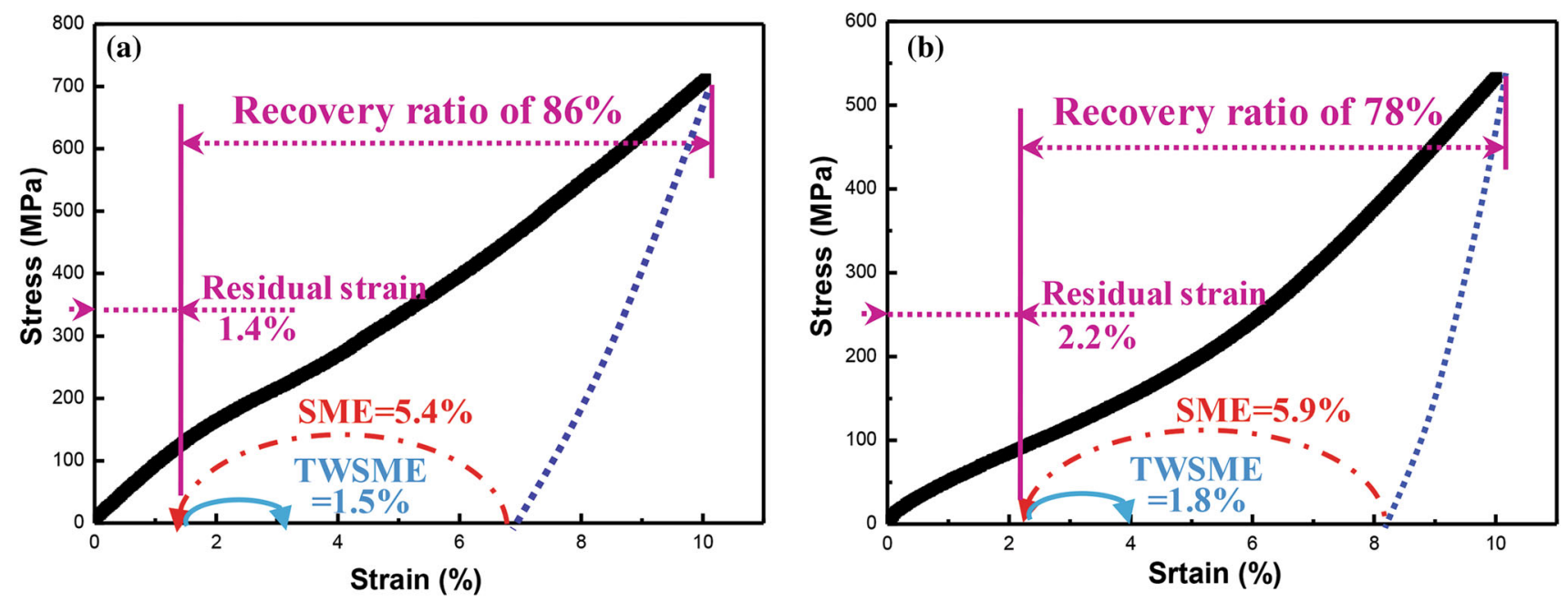

Fig. 4 Strain recovery characteristic curves of $\mathrm{Cu}_{2}$ alloy $\mathbf{a}$ and $\mathrm{Cu}_{3}$ alloy $\mathbf{b}$ under the pre-strain of $10 \%$. The red arrow line represents recovery strain after being heated to $500{ }^{\circ} \mathrm{C}$ for $1 \mathrm{~min}$, and the blue arrow is the strain after being cooled from $500{ }^{\circ} \mathrm{C}$ to room temperature

effectively improved by $\mathrm{Fe}$ addition via strengthening the grain boundaries.

It is known that the stress-strain curve of traditional HTSMAs consists of three stages, including elastic deformation of the martensite, martensitic variant reorientation and elastic-plastic deformation of fully reoriented martensite [8]. It is difficult to distinguish the deformation stages of $\mathrm{Cu}_{1}$ due to the small changes in the slope of stress-strain curve. However, the stress-strain curves of $\mathrm{Cu}_{2}$ and $\mathrm{Cu}_{3}$ can be easily divided into three obvious stages (I, II, III) according to various slopes. In addition, the yield strength is decreased by $\mathrm{Gd}$ and Fe doping, indicating that the critical stress of variant reorientation is reduced.

It is found that the SME of $\mathrm{Cu}_{1}$ is $<1.5 \%$. In fact, the poor SME is not the intrinsic characteristic of polycrystalline $\mathrm{Cu}-\mathrm{Al}-\mathrm{Ni}$ alloys. However, the severe brittleness makes the irreversible deform or fracture occur before completing the pre-strain. Therefore, the SME of $\mathrm{Cu}_{2}$ and $\mathrm{Cu}_{3}$ is significantly enhanced owe to the improvement in the mechanical properties. Figure 4 shows the strain recovery characteristic curves of $\mathrm{Cu}_{2}$ and $\mathrm{Cu}_{3}$ alloys under pre-strain of $10 \%$, and the red arrow dotted line represents recovery strain after being heated to $500{ }^{\circ} \mathrm{C}$ for $1 \mathrm{~min}$. It can be seen that the $\mathrm{Cu}_{2}$ exhibits large reversible strain (SME) of $5.4 \%$ and recovery ratio of $86 \%$ after being heated, and the residual strain is only $1.4 \%$ as shown in Fig. 4 a. The reversible strain, recovery ratio and residual strain of $\mathrm{Cu}_{3}$ alloy are $5.9 \%, 78 \%$ and $2.2 \%$, respectively (Fig. 4b). Fe doping improves the reversible strain, but reduces the recovery ratio. Under the same pre-strain condition, $\mathrm{Cu}_{3}$ alloy has a larger residual strain.

It is worth noticing that the samples were contracted again when the temperature dropped to room temperature as shown by the blue arrow line. Obviously, this is the two- way shape memory effect (TWSME), and the two-way reversible strains of $\mathrm{Cu}_{2}$ and $\mathrm{Cu}_{3}$ alloys are about $1.5 \%$ and $1.8 \%$, respectively. To date, the TWSME of some reported polycrystalline $\mathrm{Cu}-\mathrm{Al}-\mathrm{Ni}$ HTSMAs is only about $1.0 \%$ $[18,29,30]$, evidently smaller than that of our work.

\section{Conclusion}

A small number of $\mathrm{Gd}$ and $\mathrm{Fe}$ elements were added into $\mathrm{Cu}-11.9 \mathrm{Al}-3.8 \mathrm{Ni}$ HTSMA to enhance the mechanical properties and SME. Both $\mathrm{Cu}-11.9 \mathrm{Al}-3.8 \mathrm{Ni}-0.2 \mathrm{Gd}$ alloy and $\mathrm{Cu}-11.9 \mathrm{Al}-3.8 \mathrm{Ni}-2.0 \mathrm{Fe}-0.2 \mathrm{Gd}$ alloy displayed the fine grain and single-phase $\beta_{1}^{\prime}$ martensite at room temperature, and their compressive fracture strains reached $12.0 \%$ and $17.8 \%$, respectively. When the pre-strain was $10 \%$, the $\mathrm{SME}$ of $\mathrm{Cu}-11.9 \mathrm{Al}-3.8 \mathrm{Ni}-0.2 \mathrm{Gd}$ alloy and $\mathrm{Cu}-11.9 \mathrm{Al}-$ $3.8 \mathrm{Ni}-2.0 \mathrm{Fe}-0.2 \mathrm{Gd}$ alloy after being heated was $5.4 \%$ and $5.8 \%$, respectively. The obvious TWSME was observed in the samples after cooling again.

Acknowledgment The study was supported by the China Postdoctoral Science Foundation Funded Project (No. 2015M571269).

\section{References}

[1] J. Van Humbeeck, J. Eng. Mater. Technol. 121, 98 (1999)

[2] K. Otsuka, X.B. Ren, Intermetallics 7, 511 (1999)

[3] C.L. Tan, J.X. Jiang, X. An, H.J. Ge, B. Zhao, J. Alloy. Compd. 509, 7549 (2011)

[4] D. Golberg, Y. Xu, Y. Murakami, S. Morito, K. Otsuka, Scr. Metall. Mater. 30, 1349 (1994)

[5] D. Golberg, Y. Xu, Y. Murakami, Mater. Lett. 22, 241 (1995)

[6] K.V. Ramaiah, C.N. Saikrishna, Gouthama, S.K. Bhaumik, Mater. Des. 56, 78 (2014) 
[7] P.J.S. Buenconsejo, H.Y. Kim, H. Hosoda, S. Miyazaki, Acta Mater. 57, 1068 (2009)

[8] Y.Q. Ma, C.B. Jiang, Y. Li, H.B. Xu, C.P. Wang, X.J. Liu, Acta Mater. 55, 1533 (2007)

[9] H.B. Xu, Y.Q. Ma, C.B. Jiang, Appl. Phys. Lett. 82, 3206 (2003)

[10] S.Y. Yang, Y.Q. Ma, H.F. Jiang, X.J. Liu, Intermetallics 19, 225 (2011)

[11] Y.Q. Ma, S.L. Lai, S.Y. Yang, Y. Luo, C.P. Wang, X.J. Liu, Trans. Nonferrous Met. Soc. China 21, 96 (2011)

[12] Y. Xin, Y. Li, L. Chai, H.B. Xu, Scr. Mater. 57, 599 (2007)

[13] S.N. Saud, E. Hamzah, T. Abubakar, H.R. Bakhsheshi-Rad, S. Farahany, A. Abdolahi, M.M. Taheri, J. Alloy. Compd. 612, 471 (2014)

[14] V. Recarte, J.I. Pérez-Landazábal, M.L. Nó, J.S. Juan, Mater. Sci. Eng. A 370, 488 (2004)

[15] N. Zárubová, J. Gemperlová, V. Gärtnerová, A. Gemperle, Mater. Sci. Eng. A 481-482, 457 (2008)

[16] A. Amini, H. Beladi, N. Hameed, F. Will, J. Alloy. Compd. 545, $222(2012)$

[17] S. Miyazaki, T. Kawai, K. Otsuka, J. Le, De Phys. Colloques 43(C4), 813 (1982)

[18] S.K. Vajpai, R.K. Dube, S. Sangal, Mater. Sci. Eng. A 570, 32 (2013)
[19] S.N. Saud, E. Hamzah, T. Abubakar, M.K. Ibrahim, A. Bahador, Appl. Phys. A 117, 767 (2014)

[20] S.N. Saud, B. Abu, A. Tuty, E. Hamzah, M.K. Ibrahim, A. Bahador, Metall. Mater. Trans. A 46A, 3528 (2015)

[21] C.A. Canbay, Z.K. Genc, M. Sekerci, Appl. Phys. A 115, 371 (2014)

[22] X. Zhang, J.H. Sui, X.H. Zheng, Z.Y. Yang, X.H. Tian, W. Cai, J. Alloy. Compd. 557, 60 (2013)

[23] X. Zhang, J.H. Sui, X.H. Zheng, Z.Y. Yang, W. Cai, Mater. Sci. Eng. A 597, 178 (2014)

[24] A.L. Liu, W. Cai, Z.Y. Gao, L.C. Zhao, Mater. Sci. Eng. A 438, 634 (2006)

[25] U. Sari, I. Aksoy, J. Alloy. Compd. 417, 138 (2006)

[26] V. Recarte, R.B. Perez-Saez, E.H. Bocanegra, M.L. No, J.S. Juan, Metall. Mater. Trans. A 33, 2581 (2002)

[27] U. Sari, T. Kirindi, Mater. Charact. 59, 920 (2008)

[28] Y.Y. Li, J.M. Wang, C.B. Jiang, Mater. Sci. Eng. A 528, 6907 (2011)

[29] S.K. Vajpai, P.K. Dube, P. Chatterjee, S. Sangal, Metall. Mater. Trans. A 43, 2484 (2012)

[30] H. Scherngell, A.C. Kneissl, Acta Mater. 50, 327 (2002) 